\title{
Individual variation in children's reading comprehension across digital text types
}

\author{
Sabine S. Fesel, Eliane Segers and Ludo Verhoeven \\ Behavioural Science Institute, Radboud University, Nijmegen, The Netherlands
}

\begin{abstract}
The present study examined children's digital text comprehension of digital text types linear digital text vs hypertext, with or without graphical navigable overviews. We investigated to what extent individual variation in children's comprehension could be explained by lexical quality (word reading efficiency and vocabulary knowledge), cognitive load factors (prior knowledge and working memory), text type and graphical overview. Participants were 93 sixth graders in a within-subject design. Word reading efficiency, vocabulary knowledge and prior knowledge predicted children's digital comprehension scores, while working memory did not. Reading comprehension was equal for linear text or hypertext. However, the presence of an overview facilitated reading comprehension for readers with lower prior knowledge. It can be concluded that hypertexts with basic digital text features and accompanying comprehension questions are not more difficult for children than linear digital texts, that similar individual factors predict reading comprehension of linear text and hypertext, and that a graphical overview helps when prior knowledge is low.
\end{abstract}

Children in primary schools read digital text for educational goals, but comprehending nonlinear digital text is essentially different from printed linear text (Mangen, Walgermo \& Brønnick, 2013). Digital text is text presented on a screen. It can have a linear structure, but when presented on the Internet, it often contains embedded hyperlinks. This is then called a hypertext, which may have a hierarchical or networked structure. A hierarchical hypertext follows a tree-like structure, while a networked hypertext has a more complex structure, with no clear beginning or ending but with an interconnected series of nodes. Digital texts may also contain overviews that represent the structure of the text. Skilled readers enter a hypertext with adjusted reading skills (Kumbruck, 1998); they often have a question for which they have already activated their prior knowledge. These skilled readers direct their reading behaviour to answer their question while navigating in a coherent way to avoid getting 'lost' in the text. Therefore, considerable research has emphasised that the reading of digital text, and more specifically the reading of hypertext, with or without navigable graphical overviews requires adjusted linguistic reading strategies and processing resources in comparison with linear printed text (Kumbruck, 1998; Mangen, 2008; Mangen et al., 2013; Waniek \& Ewald, 2008). According to the lexical quality hypothesis, the quality of word representations affects comprehension (Perfetti, 2007). This entails not only knowing what a word means but also being able to quickly retrieve this meaning from the lexicon and being able to efficiently decode a word. Efficient word 
reading is relevant with regard to lexical quality because it indicates a high quality of phonological and orthographic word knowledge. In line with this, a reader who can read efficiently and retrieve word meaning from his or her lexicon can establish fast word-to-text integration and comprehend a text (Perfetti \& Stafura, 2014). Both word reading efficiency and the size of the lexicon have been established as predictors of printed linear text comprehension, with the latter becoming more important over the years (Protopapas, Sideridis, Mouzaki \& Simos, 2007; Verhoeven \& Van Leeuwe, 2008). In perspective of the cognitive load theory, prior knowledge and working memory can be seen as additional predictors of printed and digital text comprehension (Amadieu, Tricot \& Mariné, 2009a; Calisir, Eryazici \& Lehto, 2008; DeStefano \& LeFevre, 2007; Kirschner, Kester \& Corbalan, 2011; Zumbach \& Mohraz, 2008). Children read digital texts with less automatised reading skills than adults and often with low prior knowledge, as they read to learn (Lawless, Mills \& Brown, 2003; Salmerón \& García, 2011). However, it is by no means clear how children's digital reading comprehension is affected by different hierarchically structured digital text types and the presence or absence of graphical overviews and how individual differences can be explained. Therefore, in the present study, we examined children's individual variation in digital text comprehension as a function of lexical quality (word reading efficiency and vocabulary knowledge), cognitive load factors (prior knowledge and working memory) and of different digital text types (linear text vs hypertext) with or without an overview.

\section{Literature review}

Reading digital text on the Internet with embedded hyperlinks or graphical overviews is different from reading linear digital text without hyperlinks (Kumbruck, 1998; Mangen et al., 2013). Hypertexts give the reader flexibility in acquiring the text material in an adaptive way to the reader's goals. However, the drawback of this flexibility is the larger risk of comprehension problems because multiple paths connect different text sections and the reader has to determine a coherent reading path during reading (Amadieu, Tricot \& Mariné, 2010; DeStefano \& LeFevre, 2007; Foltz, 1996; Salmerón, Cañas, Kintsch \& Fajardo, 2005). Empirical research has generally shown the enhanced difficulty of comprehending and learning from hypertext (Bezdan, Kester \& Kirschner, 2013; DeStefano \& LeFevre, 2007; Wells \& McCrory, 2011).

It can, however, also be argued that when a hypertext is hierarchically structured, this could support a coherent reading order, exactly because of this clear structure (Waniek, 2012). When there is global coherence in the digital text, the reader needs to make fewer inferences to understand the meaning of the text (Zumbach, 2006; Zumbach \& Mohraz, 2008). In line with this, Calisir et al. (2008) as well as Amadieu et al. (2010) showed that reading comprehension of skilled readers in hierarchical digital text was higher than their reading comprehension of linear text or networked digital text. Klois, Segers and Verhoeven (2013)showed that 13-year-olds drew more complex mind maps after reading a hypertext than after reading a linear digital text. Hierarchical digital text has a clear structure and gives global coherence because the information is ordered so that more general text parts contain links to more specific texts. This is in contrast to networked digital text, in which different texts are linked to each other in a more nonlinear fashion.

Navigable graphical overviews may also support the reader to grasp the digital text structure (Bezdan et al., 2013; Jin, 2013; Salmerón, Baccino, Cañas, Madrid \& Fajardo, 2009; 
Vörös, Rouet \& Pléh, 2011). Research with undergraduate students as well as middle school students has shown that clear structured graphical overviews may help the reader to coherently navigate the text (i.e., reduced working memory demands for navigation and decisionmaking) and better comprehend the text than when there is no graphical overview (Amadieu et al., 2010; Naumann, Richter, Flender, Christmann \& Groeben, 2007; Potelle \& Rouet, 2003; Salmerón \& García, 2011; Salmerón et al., 2009). However, overviews can also restrain comprehension when the navigation path in digital text is restricted in such a way that a reader can only go one node up or down, and cannot jump to any page in the text (Bezdan et al., 2013). A restricted navigation path interrupts hypertext reading because relevant content cannot be accessed (Bezdan et al., 2013). In general, simple structured overviews that support low prior knowledge readers to navigate through the digital text and to construct their own organisation of the information have produced the best recall results because they provide cohesion, which helps to create a coherent mental representation of the text (Amadieu, Van Gog, Paas, Tricot \& Mariné, 2009b; Dee-Lucas \& Larkin, 1995).

\section{Individual differences in digital text comprehension}

Reading comprehension of linear text includes many different cognitive processes from bottom-up processes (word-based) to top-down comprehension processes (knowledgebased; Hersch \& Andrews, 2011; Perfetti, Landi \& Oakhill, 2005; Verhoeven \& Graesser, 2008). Studies on the individual variation in linear, printed text comprehension with children showed that reading comprehension is largely predicted by the quality of children's lexical representations (i.e., lexical quality; see Hersch \& Andrews, 2011; Perfetti, 2007; Richter, Isberner, Naumann \& Neeb, 2013). These differences in lexical representations of words may also explain individual differences in digital text comprehension. This is in line with results from Sullivan and Puntambekar (2015), who found general reading comprehension to support comprehension of digital texts.

Reading and learning from a text has cognitive demands, but the reader has only limited processing capacity (Mayer \& Moreno, 2003). Reading digital text seems to demand additional cognitive activities from the reader because drawing inferences for higher levels of comprehension and keeping track of the reading path during reading require cognitive resources of the working memory (DeStefano \& LeFevre, 2007; Wenger \& Payne, 1996). In other words, the flexibility that the reader has in choosing his or her own reading order of a digital text may enhance cognitive load (Bezdan et al., 2013; Kirschner et al., 2011; Paas, Tuovinen, Tabbers \&Van Gerven, 2003; Sweller, 2005; Zumbach \& Mohraz, 2008). Research of digital text comprehension thus should consider the matter of prior knowledge and working memory, which are typical measures of cognitive load (Amadieu et al., 2009a; Baddeley, 2012; Naumann, Richter, Christmann \& Groeben, 2008; Ozuru, Dempsey \& McNamara, 2009).

Overviews may be beneficial to readers who experience high cognitive load to grasp the macrostructure of the text and may help in selecting a coherent navigation pattern (DeStefano \& LeFevre, 2007; Salmerón et al., 2009). Naumann et al. (2007) found that overviews are beneficial for navigation and improve text comprehension in learners with lower reading skills or lower working memory. Especially for children, cognitive load may be high, as they often have low prior knowledge of a text and their working memories are still developing. Indeed, Salmerón and García $(2011,2012)$ found that children's digital text reading, especially without graphical overview, may easily lead to cognitive overload 
and comprehension problems. In other words, the digital text features may change the reading behaviour of the reader (see also Klois et al., 2013) and therefore word reading efficiency, vocabulary knowledge, level of prior knowledge and working memory capacity should all be considerations when investigating children's digital text comprehension.

\section{The present study}

Most researchers of digital text comprehension so far have examined digital text comprehension of skilled readers in complex learning scenarios, with demanding comprehension or learning tasks, but the findings are equivocal for children's reading comprehension tasks (Salmerón \& García, 2012). Research on digital text comprehension has primarily focused on cognitive load in skilled readers with low prior knowledge but without taking into account individual differences with regard to word reading efficiency, vocabulary knowledge, prior knowledge and working memory and without studying less skilled readers. Making inferences may consume cognitive resources of the limited working memory of less skilled readers, without appropriate prior knowledge, resulting in lower comprehension (Nation, 2005). A meta-analysis by Carretti, Borella, Cornoldi and De Beni (2009) indeed revealed that deficits in reading comprehension could be partly attributed to a shortage of the working memory control mechanisms. The degree to which the results of adults' digital text reading comprehension research can be generalised to children's digital text comprehension is limited and should be viewed with caution because of differences in the comprehension task demands.

Previous research indicated that individual variation in children's digital text comprehension might be explained by lexical quality (operationalised as word reading efficiency and vocabulary knowledge; see Verhoeven, Van Leeuwe \& Vermeer, 2011) and cognitive load factors (prior knowledge and working memory; see Kirschner et al., 2011), as well as text types (linear digital text or hypertext) and graphical overview (present or absent). We therefore investigated the following research questions:

1 To what extent can the individual variation in digital reading comprehension be explained from word reading efficiency, vocabulary knowledge, prior knowledge and working memory, as well as text type and overviews?

2 Do digital text type and navigable graphical overviews moderate the relation between individual characteristics and reading comprehension?

We expected individual child characteristics, text type and overviews to each account for significant variance in children's digital text comprehension. As such, we hypothesised that word reading efficiency and vocabulary would predict children's reading comprehension based on the lexical quality hypothesis. In line with the cognitive load theory, we also assumed prior knowledge and working memory to predict children's digital text comprehension. We hypothesised that hyperlinks would have a negative effect on comprehension, while navigable graphical overviews would facilitate text comprehension. Finally, we expected the role of individual differences in word reading efficiency, vocabulary knowledge, prior knowledge and working memory to be less strong in the case of digital texts with hyperlinks and stronger when the texts are supported by overviews. 


\title{
Method
}

Participants

In the present study, 106 children from five 6th-grade classes (54 girls and 52 boys) with a mean age of 11 years and 8 months $(S D=4.98$ month) participated. Thirteen children were excluded because of incomplete data or absence during data collection. The final sample of the present study included 93 6th-grade children (51 girls and 42 boys) with a mean age of 11 years and 7 months $(S D=5.16$; age range: 10 years and 7 months to 12 years and 6 months). As a control measure, Raven's Standard Progressive Matrices (Raven, Raven \& Court, 2003) was assessed with $M=43.64$ ( $S D=6.25$, range 29-55) as group average, indicating a sample with average and normal general cognitive ability. Two Dutch primary schools, with an average social economic status and a low percentage of children from ethnic minorities in the southern part of the Netherlands, were recruited by letter. Furthermore, children's computer literacy was examined with a computer and Internet experience questionnaire including seven items with a total score of 26 (Citogroep, http://kennisnet.nl; http://www.toetswijzer.nl/html/internetvaardigheid/vragenlijst.pdf). The computer literacy questionnaire evidenced that children were experienced in working with a computer and on the Internet $(M=21.61 ; S D=2.34)$. The children were unfamiliar with the purpose of the experiment. The primary caregivers provided their informed written consent.

\section{Materials}

Text materials. In the present study, we investigated the children's differences in reading comprehension among four digital text types in which the absence and presence of overviews and hyperlinks were systematically varied: linear digital text, digital text with navigable graphical overview, digital text with embedded hyperlinks and hypertext with navigable graphical overview (see Appendix and Figures 1-4 respectively). The children

\section{Kennismaking met Zuid-Amerika}

\author{
Sinds Christophorus Columbus de oversteek naar Zuid-Amerika maakte, zijn velen hem \\ gevolgd. Dit continent heeft vele extremen te bieden, het herbergt een scala aan \\ rijkdommen en onontdekte schatten. Hier lokt het avontuur en verdrijt de schijnbaar \\ ongerepte natuur het moderne leven naar de achtergrond. Zuid-Amerika is zowel \\ exotisch als vertrouwd. Alle denkbare klimaten, reliëfs en vegetaties zijn hier aanwezig \\ en de vele kleuren steken fel tegen elkaar af. Bovendien heeft dit continent vele \\ natuurlijke bestaansmiddelen die vele zakenlieden aantrekken. Kortom, een continent \\ dat blijft verrassen.
}

Volgende pagina

\section{$1 / 11$}

Figure 1. Screen capture from a linear digital text and an English translation. [Colour figure can be viewed at wileyonlinelibrary.com] 
read four Dutch digital texts, presented in a random order and counterbalanced with four different geographical topics $(M=974$ words, $S D=36.21)$. Each text consisted of 10 pages and had a word length of about 1000 words (Oceania: 1014 words; Russia: 946 words; South America: 982; South Africa: 939 words; see Appendix for an English translation of one passage). To accomplish a hierarchical structure of the texts, the topic was introduced on the first page, followed by three main chapters and two subchapters per main chapter for each text. The linear digital text (Figure 1) contained forward and backward buttons, so that the children could navigate between the pages. The digital text with navigable graphical overview (Figure 2) contained the regular linear text supplemented with a hierarchical and navigable overview at the top of each page. The children had to click on one of the 10 hyperlinks in the overview to navigate between the pages. Therefore, this digital text type is nonlinear because the children choose their reading order by clicking on the hyperlinks in the navigable overview in a nonrestricted individual order. The hypertext (Figure 3) contained the regular linear text and 10 hyperlinks in total that were identical to the keywords of the overview of the digital text with navigable graphical overview. The hyperlinks were standard blue, underlined and changed from blue to grey after

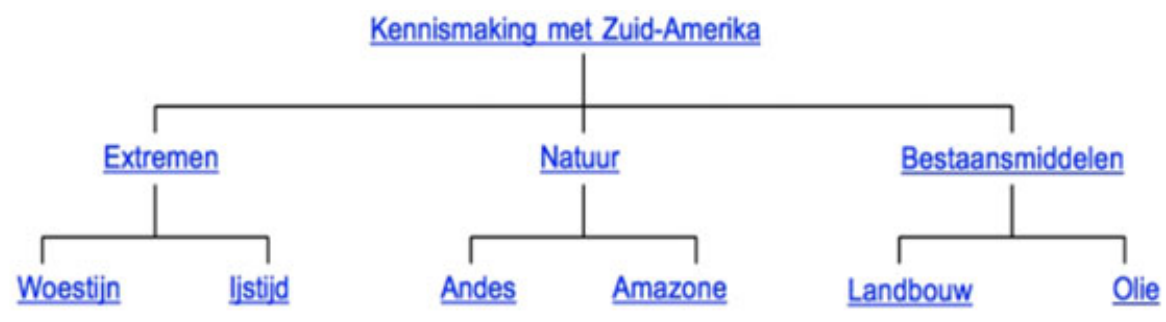

\section{Kennismaking met Zuid-Amerika}

Sinds Christophorus Columbus de oversteek naar Zuid-Amerika maakte, zijn velen hem gevolgd. Dit continent heeft vele extremen te bieden, het herbergt een scala aan rijkdommen en onontdekte schatten. Hier lokt het avontuur en verdrijt de schijnbaar ongerepte natuur het moderne leven naar de achtergrond. Zuid-Amerika is zowel exotisch als vertrouwd. Alle denkbare klimaten, reliëfs en vegetaties zijn hier aanwezig en de vele kleuren steken fel tegen elkaar af. Bovendien heeft dit continent vele natuurlijke bestaansmiddelen die vele zakenlieden aantrekken. Kortom, een continent dat blijft verrassen.

\section{Klaar met lezen}

Figure 2. Screen capture from a digital text with overview. [Colour figure can be viewed at wileyonlinelibrary. com] 


\title{
Kennismaking met Zuid-Amerika
}

\author{
Sinds Christophorus Columbus de oversteek naar Zuid-Amerika maakte, \\ zijn velen hem gevolgd. Dit continent heeft vele extremen te bieden, het \\ herbergt een scala aan rijkdommen en onontdekte schatten. Hier lokt het \\ avontuur en verdrijt de schijnbaar ongerepte natuur het moderne leven \\ naar de achtergrond. Zuid-Amerika is zowel exotisch als vertrouwd. Alle \\ denkbare klimaten, reliëfs en vegetaties zijn hier aanwezig en de vele \\ kleuren steken fel tegen elkaar af. Bovendien heeft dit continent vele \\ natuurlijke bestaansmiddelen die vele zakenlieden aantrekken. Kortom, \\ een continent dat blijt verrassen.
}

Klaar met lezen

Figure 3. Screen capture from a hypertext. [Colour figure can be viewed at wileyonlinelibrary.com]

clicking on them. The hypertext with navigable graphical overview (Figure 4) contained the hypertext supplemented by the same hierarchically structured graphical and navigable overview as in the digital text with navigable graphical overview. Therefore, the hypertext with navigable graphical overview contained 20 links in total. In the digital text with embedded hyperlinks and hypertext with navigable graphical overview, the hyperlinks per page linked to all possible pages of the next level of the hierarchy. Therefore, per page, a number of two or three hyperlinks were embedded.

To ensure an experimental within-subject design with control for possible differences in difficulty of content, all children read all four digital text types in a random order. In addition, the four digital text types were designed in four different text topics in Dutch (Oceania, Russia, South America and South Africa; The Reader's Digest, 2002) of informative geography textbooks written for this age, to exclude an effect of text topic: 4 text types $\times 4$ topics, resulting in 16 text materials. The four digital text types and the four text topics were counterbalanced and presented in a random order to reduce order effects.

Reading comprehension. To assess the children's reading comprehension of the four texts, 20 multiple choice (MC) questions for each topic (Oceania, Russia, South America and South Africa), with four possible answers, were used (see Authors, 2013). The children could receive one point for each correctly answered question. The questions were both explicit comprehension questions and implicit comprehension questions within the scope of 


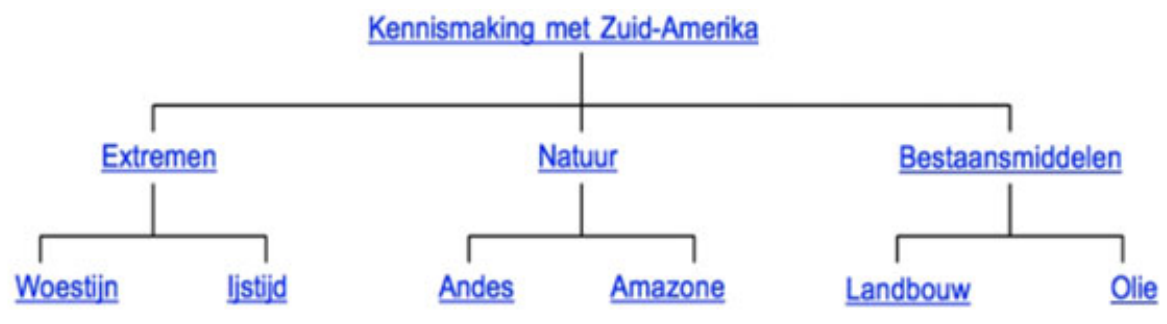

\title{
Kennismaking met Zuid-Amerika
}

\author{
Sinds Christophorus Columbus de oversteek naar Zuid-Amerika maakte, zijn velen hem \\ gevolgd. Dit continent heeft vele extremen te bieden, het herbergt een scala aan \\ rijkdommen en onontdekte schatten. Hier lokt het avontuur en verdrijt de schijnbaar \\ ongerepte natuur het moderne leven naar de achtergrond. Zuid-Amerika is zowel \\ exotisch als vertrouwd. Alle denkbare klimaten, reliëfs en vegetaties zijn hier aanwezig \\ en de vele kleuren steken fel tegen elkaar af. Bovendien heeft dit continent vele \\ natuurlijke bestaansmiddelen die vele zakenlieden aantrekken. Kortom, een continent \\ dat blijft verrassen.
}

\section{Klaar met lezen}

Figure 4. Screen capture from a hypertext with overview. [Colour figure can be viewed at wileyonlinelibrary.com]

the relevant text (example of an explicit question: 'The Kagu in Oceania belongs to which species group? (a) Mammals, (b) Birds, (c) Reptiles, (d) Insects'; example of an implicit question: 'Why is a tree in Oceania called breadfruit tree? (a) Because the fruits are the same for the people in Oceania as fresh bread is for us, (b) Because the fruit tastes similar to bread, (c) Because the fruits look like cinnamon buns (d) Because many birds brood in the trees') Previous results showed a sufficient alpha for the explicit MC questions $(\alpha=.84)$ and implicit MC questions ( $\alpha=.73$ ) (see Authors, 2013). The children were able to refer back to relevant text passages while answering the comprehension questions. Per text topic, the comprehension questions were printed out on paper to ensure that the children can read the whole text on the computer screen.

Word reading efficiency. To assess word reading efficiency, a standardised test was used in which the children had to read words from a word list as fast as possible in 1 minute (Een Minuut Test; Van Brus \& Voeten, 1973). The list contains 116 (real) words, which increase in difficulty. The total score is calculated by counting the words that were read correctly within 1 minute. 
Vocabulary knowledge. The children's vocabulary knowledge was assessed with a paperand-pencil standardised vocabulary test, consisting of 36 items (Woordenschattest; Aarnoutse, 1989). During the test, the participant has to choose the word that is closest in meaning to the word in a sentence offered. The participant can choose from four alternative explanations. The test starts with three sample items, and was assessed in class, following the instructions in the manual. The total score is the number of items answered correctly.

Prior knowledge. Pre-test questions were extracted from the MC questions of the four texts to assess the amount of prior knowledge of the children. Four MC questions per text, two detail comprehension questions and two global comprehension questions were chosen at random. In total, the prior knowledge test contained $16 \mathrm{MC}$ questions. It should be noted that these were again asked during the reading comprehension of the texts. The children received one point for each correctly answered question.

Working memory. The children's working memory span was assessed with the digit span test from the Wechsler Intelligence Scale for Children-III (Kaldenbach, 2010; Kort et al., 2005). The digit span test is a subtest of the Wechsler Intelligence Scale, in which the participant has to hold a string of numbers in working memory, while reproducing the numbers in the same order (digit span forward) or backward (digit span backward). The span of digits increases from two to seven during the test phase. The test starts with the digit span forward and continues with the digit span backward. The test stops when the first and second trials of one digit span are wrong. Total test scores were calculated from the digit span forward and digit span backward scores, with one point per correct item. The maximum test score was 30 .

\section{Procedure and experimental design}

All children were tested in Dutch. First, the children were tested individually on word reading efficiency and working memory span; this took approximately 15 minutes. The children were next tested in their classes for the pretest MC questions, vocabulary test and computer literacy; this took approximately 40 minutes. Due to the time delay of 2 months between the pretest of the child characteristics and the actual experiment, an effect of the prior knowledge questions on the comprehension measures of the experiment can be excluded, especially because no feedback was given.

The experimental phase started 2 months later. The experiment was conducted in four lessons (45 minutes) distributed over 4 days. The children were distributed at random in a within-subject design, to control for text content, over the four text types and four topics within these four lessons. Thus, the children read all four text types but about different topics, in a randomised block design. For example, one child read in the linear digital text type about Russia, in digital text with navigable graphical overview about Oceania, in digital text with embedded hyperlinks about South America and in hypertext with navigable graphical overview about South Africa. Another child read the same text types but about other topics: in linear digital text about South Africa, in digital text with navigable graphical overview about Russia, in digital text with embedded hyperlinks about Oceania and in hypertext with navigable graphical overview about South America. During the four reading sessions in the computer classroom, the children received written instructions, which were further clarified via oral explanation. They were instructed to read the text carefully and to answer the $20 \mathrm{MC}$ questions that they received in print at the same time as the texts became 
available on screen. The children read the texts in full screen mode, and there was no time limit. The children had to click on a 'finished reading' button on the last page of the linear digital text version and on the introduction page of the other three versions after finishing reading and answering all questions.

\section{Results}

The pretest scores for the children's prior knowledge as measured by using a subset of the MC questions (16 questions; $M_{\text {correct }}=5.68$ [i.e., $35.5 \%$ correct], $S D=2.12 ; M_{\text {chance- }}$ level $=4.00$ ) confirmed that they were low prior knowledge readers of the four geography topics. The within-subject design of the present study controlled for any possible differences in difficulty of the questions regarding the four different topics. Table 1 presents the descriptive statistics of the children's linguistic and cognitive predictors as well as reading comprehension scores in the four digital text conditions. As can be seen, all scores were distributed normally, with skewness and kurtosis within normal levels. Table 2 shows the correlations between the different variables.

To answer our research questions, we ran a generalised linear model repeated measures analysis with text type (linear and hypertext) and overview (present and absent) as withinsubject variables and word reading efficiency, vocabulary knowledge, prior knowledge and working memory as covariates. We explicitly tested for interactions between the covariates and the within-subject factors to answer the second research question. The results showed no main effects of text type or overview, $F(1,80)=1.09, p=.30, \eta_{\mathrm{p}}^{2}=0.01 ; F(1,80)=0.09$, $p=.76, \eta_{\mathrm{p}}^{2}<0.01$. Individual factors contributed to reading comprehension; there were main effects of word reading efficiency, $\left.F(1,80)=41.33, p<.01, \eta_{\mathrm{p}}^{2}=0.34\right)$; vocabulary knowledge, $\left.F(1,80)=43.78, p<.01, \eta_{\mathrm{p}}^{2}=0.35\right)$; and prior knowledge, $F(1,80)=4.92$, $p=.03, \eta_{\mathrm{p}}^{2}=0.06$, but the main effect of working memory was not significant, $F(1,80)=3.48, p=.07, \eta_{\mathrm{p}}^{2}=0.04$. Furthermore, the interactions between text type and the individual factors were not significant (all $F \mathrm{~s}<1$ ), and this was the same for the interaction between overview and the individual factors (overview * reading efficiency, $F<1$; overview $*$ vocabulary knowledge, $F[1,80]=1.53, p=.22, \eta_{\mathrm{p}}^{2}=0.02$; overview $*$ working memory, $F[1,80]=2.33, p=.13, \eta_{\mathrm{p}}^{2}=0.03$ ), with the exception of the interaction between overview and prior knowledge, $F(1,80)=5.63, p=.02, \eta_{\mathrm{p}}^{2}=0.06$. The correlation between

Table 1. Descriptive statistics among word reading efficiency, vocabulary knowledge, prior knowledge, working memory and the four digital text types.

\begin{tabular}{lrrrrr}
\hline & $M$ & $S D$ & Range & Skewness & Kurtosis \\
\hline Word reading efficiency & 75.30 & 14.73 & $36-107$ & 0.16 & -0.54 \\
Vocabulary knowledge & 28.57 & 4.50 & $14-36$ & -0.62 & 0.33 \\
Prior knowledge & 5.68 & 2.12 & $0-10$ & -0.12 & -0.12 \\
Working memory & 12.92 & 2.60 & $7-20$ & 0.23 & 0.19 \\
Reading comprehension linear digital text & 12.96 & 3.50 & $4-20$ & -0.35 & 0.03 \\
Reading comprehension digital text with overview & 12.52 & 3.19 & $4-19$ & -0.25 & -0.59 \\
Reading comprehension hypertext & 12.20 & 3.84 & $4-19$ & -0.21 & -0.96 \\
Reading comprehension hypertext with overview & 12.26 & 3.79 & $3-19$ & -0.29 & -0.59 \\
\hline
\end{tabular}


Table 2. Pearson correlations among word reading efficiency, vocabulary knowledge, prior knowledge, working memory and the four digital text types.

\begin{tabular}{|c|c|c|c|c|c|c|c|c|}
\hline & 1 & 2 & 3 & 4 & 5 & 6 & 7 & 8 \\
\hline $\begin{array}{l}\text { 1. Word decoding } \\
\text { efficiency }\end{array}$ & - & & & & & & & \\
\hline $\begin{array}{l}\text { 2. Vocabulary } \\
\text { knowledge }\end{array}$ & $0.22 *$ & - & & & & & & \\
\hline 3. Prior knowledge & 0.06 & $0.37 * *$ & - & & & & & \\
\hline $\begin{array}{l}\text { 4. Working } \\
\text { memory }\end{array}$ & $0.42 * *$ & $0.21 *$ & 0.10 & - & & & & \\
\hline $\begin{array}{l}\text { 5. Reading } \\
\text { comprehension } \\
\text { linear digital text }\end{array}$ & $0.38 * *$ & $0.55^{* *}$ & $0.43 * *$ & $0.40 * *$ & - & & & \\
\hline $\begin{array}{l}\text { 6. Reading } \\
\text { comprehension } \\
\text { digital text with } \\
\text { overview }\end{array}$ & $0.56 * *$ & $0.45 * *$ & 0.17 & $0.36 * *$ & $0.47 * *$ & - & & \\
\hline $\begin{array}{l}\text { 7. Reading } \\
\text { comprehension } \\
\text { hypertext }\end{array}$ & $0.54 * *$ & $0.43 * *$ & $0.26^{*}$ & $0.43 * *$ & $0.51 * *$ & $0.46^{* *}$ & - & \\
\hline $\begin{array}{l}\text { 8. Reading } \\
\text { comprehension } \\
\text { hypertext with } \\
\text { overview }\end{array}$ & $0.43 * *$ & $0.58 * *$ & $0.24 *$ & $0.27 * *$ & $0.52 * *$ & $0.50 * *$ & $0.47 * *$ & - \\
\hline
\end{tabular}

$* p<.05$.

$* * p<.01$.

prior knowledge and reading comprehension of the texts that contained an overview was $r(87)=.23(p=.03)$, while the correlation between prior knowledge and reading comprehension of the text that did not contain an overview was $r(90)=.39(p<.01)$. The interaction indicates that the presence of an overview moderated the relation between prior knowledge and reading comprehension. Prior knowledge was more important for the comprehension of texts that did not contain an overview, but the relation between prior knowledge and comprehension was less strong when there was an overview.

\section{Discussion}

This study focused on the role of children's individual variation in digital text comprehension and compared the comprehension of linear digital text versus hypertext with or without a navigable graphical overview. Regarding individual variation, we found, as expected, that word reading efficiency and vocabulary knowledge predicted children's digital text comprehension. Our results also indicated that prior knowledge predicted children's reading comprehension. Working memory did not add to this prediction, although an effect approached significance. Contrary to our expectations, the results revealed no influence of text type or main effect of graphical overview on children's reading comprehension. Second, with respect to the individual child characteristics, we expected that their impact would be less strong in the case of digital texts with hyperlinks and stronger when the texts 
are supported by overviews. We did not find such effects for text type, but the overview supported reading comprehension of children with lower prior knowledge.

The first set of results corresponds to previous findings related to reading comprehension of linear nondigital text (e.g., Verhoeven \& Van Leeuwe, 2008). Effect sizes for word reading efficiency and vocabulary knowledge were high, suggesting that the lexical quality hypothesis (Perfetti, 2007), which stresses the importance of word reading efficiency and vocabulary knowledge, also holds for the reading of digital text and hypertext. Regarding the cognitive load factors (prior knowledge and working memory), the effect sizes were small, but the load was equal across the different text types. The effect of prior knowledge was small but significant, whereas the effect of working memory was not significant but showed an effect size similar to that of prior knowledge. Working memory did show positive correlations to reading comprehension of the various text types with or without overview, but the effect was probably subsumed by the inclusion of word reading efficiency and vocabulary in the model. We can thus assume that simple hierarchical overviews and appropriate hyperlinks that reflect the conceptual model of the text do not disadvantage digital text comprehension (Jin, 2013; Salmerón \& García, 2012; Wenger \& Payne, 1996) and do not pose a heavy cognitive load on the children.

We did not find a main positive effect of overviews and a negative effect of hyperlinks in children's digital text comprehension nor did individual variation moderate such an effect. There was one exception: The presence of an overview facilitated reading comprehension for readers with lower prior knowledge. The fact that text type did not affect comprehension could be explained by the structure of the hypertext we used, which was hierarchical and closed. A hierarchical hypertext, as used in the present study, shows a clear macrostructure and already has clear structure. Indeed, Calisir et al. (2008) as well as Amadieu et al. (2010) showed that a hierarchical hypertext, because of its clear structure, is comprehended better than a networked hypertext. The fact that we found that overviews had a positive effect when prior knowledge was lower is fully in line with a study by Salmerón et al. (2009), who found that graphical overviews facilitated comprehension of adult readers only when such overviews are at the beginning of a relatively long and difficult hypertext but not in shorter, hierarchical hypertexts.

There are differences in design between the present study and previous research that did find effects of text type and larger positive effects of graphical overviews. For example, positive influences of hypertexts with or without graphical overviews versus linear digital texts, being found in a previous study in which children received questions after they read the text and could not look back to the text anymore (Klois et al., 2013), were probably negated by the fact that in the present study, the questions were available at the same time as the children read the text. The overview in the present study thus may not have been needed so much to help forming a situation model (nor did hyperlinks negatively influence comprehension). Reading comprehension is often measured with recall tests and MC questions after reading the text, that is, when the text is not available to refer back to answer the comprehension questions. These are partly also tests of memory (Amadieu et al., 2010; Vörös et al., 2011). Assignments for children should consider task demands and permit the reader to efficiently use their limited cognitive capacity (Paas et al., 2003). As the effort to memorise during reading can interfere with text comprehension (Andreassen \& Bråten, 2010; Smith, 1975), we decided in the present study to ask the comprehension questions when the text was available.

The present study has some limitations. First of all, we used prior knowledge and working memory as predictor measures, but these can also be regarded indirect measures 
of cognitive load. To examine the cognitive load theory more thoroughly, mental load should be measured directly through self-report questions, physiological tasks or dual tasks (Paas et al., 2003). Cognitive load during reading is a crucial and a major factor for comprehension failures in digital text with complex comprehension tasks (Bezdan et al., 2013). In more complex digital texts than used in the present study, the load on the operating resources of the working memory consequently should increase, possibly impairing children's reading comprehension (DeStefano \& LeFevre, 2007). A direct measure of cognitive load in addition to measures of children's working memory could give further insight into the cognitive load theory in digital text comprehension. Furthermore, the $2 \times 2$ design should be considered with some caution, as the overview presented in the linear text in the preceding texts had clickable hyperlinks. Children thus could navigate the text in a nonlinear way. In a previous study, we, however, evidenced that children tend to read this text linearly (Authors, 2013).

Future research should focus more on the navigational pattern in children's reading comprehension in interaction with text type and overview. Sullivan, Gnesdilow and Puntambekar (2011) did relate navigational pattern to reading comprehension but not across different text types. It would be interesting to examine differences among the four digital texts based on navigational pattern and time limitation, which we did not measure in the present study, and consider larger hypertexts that are not hierarchically structured but have a more complex, networked structure. It would also be interesting to examine the effect of having the questions together with the text versus answering them afterwards. There are some indications that the former condition may guide the children and support a coherent reading order in digital text (Salmerón et al., 2005). One also may assume that they would evoke a more strategic way of reading, not leading to a sound situation model. This former condition may also support low-level readers because it may enhance coherence during reading, which may be examined in future research. More advanced methodologies as eye-tracking could also be used to focus more on the children's reading efficacy when reading digital text compared with regular linear text. Especially, gaze data and fixation times could shed light on the interplay between individual differences as the cognitive characteristics of the reader, the reader's reading skills and reading comprehension (Dyson \& Haselgrove, 2002; Salmerón et al., 2009).

To conclude, the present study shows that hypertexts with basic digital text features and accompanying comprehension questions are not more difficult for children than linear digital texts. Moreover, linear text comprehension and hypertext comprehension turn out to be highly related. Finally, both in the comprehension of linear text and hypertext, an overview appears to facilitate reading comprehension only when prior knowledge is low.

\section{References}

Aarnoutse, C.A.J. (1989). Begrippentest en Woordenschat test, Begrijpend leestest en Leesattitudeschaal. Bestemd voor groep 5 van het basisonderwijs. Verantwoording. . [Concept test and vocabulary test, reading comprehension and reading attitude scale. Intended for grade of primary education. Accountability]. Nijmegen: Lisse: Swets \& ZeitlingerBerkhout.

Amadieu, F., Tricot, A. \& Mariné, C. (2009a). Prior knowledge in learning from a non-linear electronic document: Disorientation and coherence of the reading sequences. Computers in Human Behavior, 25, 381-388. DOI:10.1016/j.chb.2008.12.017.

Amadieu, F., Tricot, A. \& Mariné, C. (2010). Interaction between prior knowledge and concept-map structure on hypertext comprehension, coherence of reading orders and disorientation. Interacting with Computers, 22(2), 88-97. DOI:10.1016/j.intcom.2009.07.001. 
Amadieu, F., Van Gog, T., Paas, F., Tricot, A. \& Mariné, C. (2009b). Effect of prior knowledge and concept-map structure on disorientation, cognitive load, and learning. Learning and Instruction, 19, 376-386. DOI:10.1016/ j.learninstruc.2009.02.005.

Andreassen, R. \& Bråten, I. (2010). Examining the prediction of reading comprehension on different multiplechoice tests. Journal of Research in Reading, 33(3), 263-283. DOI:10.1111/j.1467-9817.2009.01413.x.

Authors (2013). Title. Computers in Human Behavior.

Baddeley, A.D. (2012). Working memory: Theories, models, and controversies. Annual Review of Psychology, 63, 1-29. DOI:10.1146/annurev-psych-120710-100422.

Bezdan, E., Kester, L. \& Kirschner, P.A. (2013). The influence of node sequence and extraneous load induced by graphical overviews on hypertext learning. Computers in Human Behavior, 29, 870-880. DOI:10.1016/j. chb.2012.12.016.

Calisir, F., Eryazici, M. \& Lehto, M. (2008). The effects of text structure and prior knowledge of the learner on computer-based learning. Computers in Human Behavior, 24(2), 439-450. DOI:10.1016/j.chb.2007.01.032.

Carretti, B., Borella, E., Cornoldi, C. \& De Beni, R. (2009). Role of working memory in explaining the performance of individuals with specific reading comprehension difficulties: A meta analysis. Learning and Individual Differences, 19, 246-251. DOI:10.1016/j.lindif.2008.10.002.

Dee-Lucas, D. \& Larkin, J.H. (1995). Learning from electronic texts: Effects of interactive overviews for information access. Cognition and Instruction, 13(3), 431-468. DOI:10.1207/s1532690xci1303_4.

DeStefano, D. \& LeFevre, J.-A. (2007). Cognitive load in hypertext reading: A review. Computers in Human Behavior, 23(3), 1616-1641. DOI:10.1016/j.chb.2005.08.012.

Dyson, M. \& Haselgrove, M. (2002). The effects of reading speed and reading patterns on the understanding of text read from screen. Journal of Research in Reading, 23(2), 210-223. DOI:10.1111/1467-9817.00115.

Foltz, P.W. (1996). Comprehension, coherence and strategies in hypertext and linear text. In J.-F. Rouet, J.J. Levonen, A.P. Dillon \& R.J. Spiro (Eds.), Hypertext and cognition. Hillsdale, NJ: Lawrence Erlbaum Associates.

Hersch, J. \& Andrews, S. (2011). Lexical quality and reading skill: Bottom-up and top-down contributions to sentence processing. Scientific Studies of Reading, 16(3), 240-262. DOI:10.1080/10888438.2011.564244.

Jin, S.-H. (2013). Visual design guidelines for improving learning from dynamic and interactive digital text. Computers \& Education, 63, 248-258. DOI:10.1016/j.compedu.2012.12.010.

Kaldenbach, Y. (2010). Hiërarchische analyse van de WISC-III nader toegelicht: vragen en antwoorden. [Hierarchical analysis of the WISC-III explained: Questions and answers]. Kind \& Adolescent Praktijk, 6(2), 58-66. DOI:10.1007/BF03059634.

Kirschner, F., Kester, L. \& Corbalan, G. (2011). Cognitive load theory and multimedia learning, task characteristics and learning engagement: The current state of the art. Computers in Human Behavior, 27, 1-4. DOI:10.1016/j.chb.2010.05.003.

Klois, S.S., Segers, E. \& Verhoeven, L. (2013). How hypertext fosters children's knowledge acquisition: Role of graphic overview and text structure. Computers in Human Behavior, 29, 2047-2057. DOI:10.1016/j. chb.2013.03.013.

Kort, W., Schittekatte, M., Dekker, P.H., Verhaeghe, P., Compaan, E.L., Bosmans, M. et al. (2005). WISC-III NL. Handleiding en Verantwoording. [WISC-III NL. Manual and accountability]. London: The Psychological Corporation.

Kumbruck, C. (1998). Hypertext reading: Novices vs. expert reading. Journal of Research in Reading, 21(2), 160-172. DOI:10.1111/1467-9817.00051.

Lawless, K.A., Mills, R. \& Brown, S.W. (2003). Children's hypertext navigation strategies. Journal of Research on Technology in Education, 34(3), 274-284.

Mangen, A. (2008). Hypertext fiction reading: Haptics and immersion. Journal of Research in Reading, 31(4), 404-419. DOI:10.1111/j.1467-9817.2008.00380.x.

Mangen, A., Walgermo, B.R. \& Brønnick, K. (2013). Reading linear texts on paper versus computer screen: Effects on reading comprehension. International Journal of Educational Research, 58, 61-68. DOI:10.1016/ j.ijer.2012.12.002

Mayer, R.E. \& Moreno, R. (2003). Nine ways to reduce cognitive load in multimedia learning. Educational Psychologist, 38(1), 43-52. DOI:10.1207/S15326985EP3801_6.

Nation, K. (2005). Children's reading comprehension difficulties. In M.J. Snowling \& C. Hulme (Eds.), The science of reading: A handbook, (pp. 248-265). Oxford: Blackwell.

Naumann, J., Richter, T., Christmann, U. \& Groeben, N. (2008). Working memory capacity and reading skill moderate the effectiveness of strategy training in learning from hypertext. Learning and Individual Differences, 18(2), 197-213. DOI:10.1016/j.lindif.2007.08.007. 
Naumann, J., Richter, T., Flender, J., Christmann, U. \& Groeben, N. (2007). Signaling in expository hypertexts compensates for deficits in reading skill. Journal of Educational Psychology, 99, 791-213. DOI:10.1037/ 0022-0663.99.4.791.

Ozuru, Y., Dempsey, K. \& McNamara, D.S. (2009). Prior knowledge, reading skill, and text cohesion in the comprehension of science texts. Learning and Instruction, 19(3), 228-242. DOI:10.1016/j. learninstruc.2008.04.003.

Paas, F., Tuovinen, J.E., Tabbers, H. \& Van Gerven, P.W.M. (2003). Cognitive load measurement as a means to advance cognitive load theory. Educational Psychologist, 38(1), 63-71. DOI:10.1207/S15326985EP3801_8.

Perfetti, C. (2007). Reading ability: Lexical quality to comprehension. Scientific Studies of Reading, 11(4), 357-383. DOI:10.1080/10888430701530730.

Perfetti, C., Landi, N. \& Oakhill, J. (2005). The acquisition of reading comprehension skill. In M.J. Snowling \& C. Hulme (Eds.), The science of reading: A handbook, (pp. 227-253). Oxford: Blackwell.

Perfetti, C. \& Stafura, J. (2014). Word knowledge in a theory of reading comprehension. Scientific Studies of Reading, 18(1), 22-37. DOI:10.1080/10888438.2013.827687.

Potelle, H. \& Rouet, J.-F. (2003). Effects of content representation and readers' prior knowledge on the comprehension of hypertext. International Journal of Human-Computer Studies, 58(3), 327-345. DOI:10.1016/ S1071-5819(03)00016-8.

Protopapas, A., Sideridis, G.D., Mouzaki, A. \& Simos, P.G. (2007). Development of lexical mediation in the relation between reading comprehension and word reading skills in Greek. Scientific Studies of Reading, 11(3), 165-197. DOI:10.1080/10888430701344322.

Raven, J., Raven, J.C. \& Court, J.H. (2003). Manual for Raven's Progressive Matrices and vocabulary scales. Research supplement no. 4: Additional national and American norms, and summaries of normative, reliability, and validity studies. Oxford, England: Oxford Psychologists Press/San Antonio, TX: The Psychological Corporation.

Richter, T., Isberner, M.-B., Naumann, J. \& Neeb, Y. (2013). Lexical quality and reading comprehension in primary school children. Scientific Studies of Reading, 00, 1-20. DOI:10.1080/10888438.2013.764879.

Salmerón, L., Baccino, T., Cañas, J.J., Madrid, R.I. \& Fajardo, I. (2009). Do graphical overviews facilitate or hinder comprehension in hypertext? Computers \& Education, 53(4), 1308-1319. DOI:10.1016/j. compedu.2009.06.013.

Salmerón, L., Cañas, J.J., Kintsch, W. \& Fajardo, I. (2005). Reading strategies and hypertext comprehension. Discourse Processes, 40(3), 171-191. DOI:10.1207/s15326950dp4003_1.

Salmerón, L. \& García, V. (2011). Reading skills and children's navigation strategies in hypertext. Computers in Human Behavior, 27, 1143-1151. DOI:10.1016/j.chb.2010.12.008.

Salmerón, L. \& García, V. (2012). Children's reading of printed text and hypertext with navigation overviews: The role of comprehension, sustained attention, and visuo-spatial abilities. Journal of Educational Computing Research, 47(1), 33-50. DOI:10.2190/EC.47.1.b.

Smith, F. (1975). Comprehension and learning. New York: Holt.

Sullivan, S., Gnesdilow, D. \& Puntambekar, S. (2011). Navigation behaviors and strategies used by middle school students to learn from a science hypertext. Journal of Educational Multimedia and Hypermedia, 20(4), $387-423$.

Sullivan, S.A. \& Puntambekar, S. (2015). Learning with digital texts: Exploring the impact of prior domain knowledge and reading comprehension ability on navigation and learning outcomes. Computers in Human Behavior, 50, 299-313. DOI:10.1016/j.chb.2015.04.016.

Sweller, J. (2005). Implications of cognitive load theory for multimedia learning. In R.E. Mayer (Ed.), The Cambridge Handbook of Multimedia Learning, (pp. 19-30). New York, NY: Cambridge University Press.

Van Brus, B.T. \& Voeten, M.J.M. (Eds.) (1973). Een-minuuttest. [One-minute test]. Nijmegen, The Netherlands: Berkhout.

Verhoeven, L. \& Graesser, A. (2008). Cognitive and linguistic factors in interactive knowledge construction. Discourse Processes, 45, 289-297. DOI:10.1080/01638530802145353.

Verhoeven, L. \& Van Leeuwe, J. (2008). Prediction of the development of reading comprehension: A longitudinal study. Applied Cognitive Psychology, 22(3), 407-423. DOI:10.1002/acp.1414.

Verhoeven, L., van Leeuwe, J. \& Vermeer, A. (2011). Vocabulary growth and reading development across the elementary school years. Scientific Studies of Reading, 15(1), 8-25. DOI:10.1080/10888438.2011.536125.

Vörös, Z., Rouet, J.-F. \& Pléh, C. (2011). Effect of high-level content organizers on hypertext learning. Computers in Human Behavior, 27(5), 2047-2055. DOI:10.1016/j.chb.2011.04.005.

Waniek, J. (2012). How information organization affects users' representation of hypertext structure and content. Behaviour \& Information Technology, 31(2), 143-154. DOI:10.1080/01449290903544652. 
Waniek, J. \& Ewald, K. (2008). Cognitive costs of navigation aids in hypermedia learning. Journal of Educational Computing Research, 39(2), 185-204. DOI:10.2190/EC.39.2.e.

Wells, A.T. \& McCrory, R. (2011). Hypermedia and learning: Contrasting interfaces to hypermedia systems. Computers in Human Behavior, 27, 195-202. DOI:10.1016/j.chb.2010.07.036.

Wenger, M.J. \& Payne, D.G. (1996). Comprehension and retention of nonlinear text: Considerations of working memory and material-appropriate processing. The American Journal of Psychology, 109(1), 93-130.

Zumbach, J. (2006). Cognitive overhead in hypertext learning re-examined: Overcoming the myths. Journal of Educational Multimedia and Hypermedia, 15(4), 411-432.

Zumbach, J. \& Mohraz, M. (2008). Cognitive load in hypermedia reading comprehension: Influence of text type and linearity. Computers in Human Behavior, 24, 875-887. DOI:10.1016/j.chb.2007.02.015.

\section{Becoming familiar with South America}

\section{Appendix}

Ever since Christopher Columbus made his way to South America, many have followed his footsteps. This continent has a lot of extremities to offer, containing a rich biodiversity with unexplored treasures. This is where adventure calls and where the seemingly untouched wilderness makes modern life disappear in the background. South America is both exotic and familiar. All known climates, heights and vegetation can be found here, and the many colours form a bright contrast. On top of that, this continent has many natural resources that attract business people. In short, this is a continent that continues to be a surprise.

Sabine Fesel has a PhD from the Behavioural Science Institute (Radboud University). Her research project was on children's digital text comprehension.

Eliane Segers is professor in reading and digital media with a special interest in how children can optimally learn in digital environments.

Ludo Verhoeven is professor in psychology and education. His research fields are remedial education (learning problems), learning and development.

Received 18 October 2013; revised version received 19 April 2016.

Address for correspondence: Eliane Segers, Behavioural Science Institute, Radboud University, PO Box 9104, 6500 HE Nijmegen, The Netherlands. E-mail: e.segers@pwo.ru.nl 